\title{
A randomized trial to evaluate a launderable bed protection system for hospital beds
}

\author{
Edmond A Hooker ${ }^{1 *}$, Steven Allen², Larry Gray ${ }^{3}$ and Cynthia Kaufman ${ }^{4}$
}

\begin{abstract}
Background: Hospital beds are potential reservoirs of bacteria in hospitals. Preventing contamination of the bed and providing a cleaner surface should help prevent hospital-acquired infections (HAls). Most hospital beds are cleaned between patients (terminal cleaning) using quaternary ammonia compounds (quats).

Objective: The study had two objectives: identify levels of bacterial contamination on beds (including the mattress and bed deck) and evaluate a new launderable cover.

Methods: Hospital beds on a bariatric surgery ward were randomized to either receive or not receive a launderable cover (Trinity Guardion, Batesville, IN). Bacterial counts on the surface of the mattress, the bed deck, and the launderable cover were then collected using Petrifilm ${ }^{\mathrm{TM}}$ Aerobic Count Plates (Petrifilm ${ }^{\mathrm{TM}}, 3 \mathrm{M}^{\mathrm{TM}}$, St. Paul, MN, USA) $\left(\right.$ Petrifilm ${ }^{T M}$ ) at three time periods (before patient use, after discharge, and after terminal cleaning). Standard hospital linen was used in all rooms.

Results: The launderable cover $(n=28)$ was significantly cleaner prior to patient use than were the cleaned mattresses ( $n=38)\left(1.1 \mathrm{CFU} / 30 \mathrm{~cm}^{2}\right.$ vs. $\left.7.7 \mathrm{CFU} / 30 \mathrm{~cm}^{2} ; p=0.0189\right)$. The mattresses without launderable covers became significantly contaminated during use $\left(7.7 \mathrm{CFU} / 30 \mathrm{~cm}^{2}\right.$ on admission vs. $79.1 \mathrm{CFU} / 30 \mathrm{~cm}^{2}$ after discharge; $p<0.001)$. The mattresses with launderable covers did not become contaminated $\left(3.0 \mathrm{CFU} / 30 \mathrm{~cm}^{2}\right.$ on admission vs. $2.5 \mathrm{CFU} / 30 \mathrm{~cm}^{2}$ at discharge; $\mathrm{p}=0.703$ ). After terminal cleaning, the mattress surface contamination decreased to $12.8 \mathrm{CFU} / 30 \mathrm{~cm}^{2}$ (median $3 \mathrm{CFU} / 30 \mathrm{~cm}^{2}$; SD 7.8), but the bed deck was more contaminated $\left(6.7 \mathrm{CFU} / 30 \mathrm{~cm}^{2}\right.$ after discharge compared to $30.9 \mathrm{CFU} / 30 \mathrm{~cm}^{2}$ after terminal cleaning; $p=0.031$ ).

Conclusions: Terminal cleaning fails to eliminate bacteria from the surface of the hospital mattress. The launderable cover provides a cleaner surface than does terminal cleaning with quats, and the cover protects the bed from contamination during use.
\end{abstract}

\section{Introduction}

It has been long recognized in the surgical arena that sterile conditions are important in order to prevent wound infections. Until recently, less emphasis has been placed on the environmental contamination outside of the operating room. In the United States, it has been estimated that hospital-acquired infections (HAIs) kill over 100,000 people each year and cost in excess of 35 billion dollars [1-3].This is mortality equivalent as a 300passenger airliner fatally crashing each day.

It is imperative that all sources of HAIs be identified, addressed and cleaned as well as possible. In every

\footnotetext{
* Correspondence: ehooker@mac.com

${ }^{1}$ Department of Health Services Administration, Xavier University, 3800

Victory Parkway, ML 5141, Cincinnati, OH 45207-7331, USA

Full list of author information is available at the end of the article
}

hospital room, there is a patient bed, which is comprised of a bed deck (frame) and a mattress. The mattress consists of different inner workings (e.g., foam or more sophisticated air mattresses) and a permanent cover that is not removed between patients. These permanent covers are most commonly made of polyurethane, nylon, or Gore-tex ${ }^{\circledR}$ surface. These mattresses must be cleaned between patients, along with the other parts of the patient room. The Centers for Disease Control and Prevention (CDC) recommended in 2003 mattresses be cared for in such a manner to prevent the spread of HAIs. In the 2003 publication on environmental infection control in healthcare facilities, the CDC acknowledged that hospital mattresses can become contaminated during patient care [4]. They recognized that the linen sheet is not a cover and that mattresses should be replaced when torn, punctured
C Biomed Central

(c) 2012 Hooker et al.; licensee BioMed Central Ltd. This is an Open Access article distributed under the terms of the Creative Commons Attribution License (http://creativecommons.org/licenses/by/2.0), which permits unrestricted use, distribution, and reproduction in any medium, provided the original work is properly cited. 
or stained. They recommended that mattresses be cleaned and disinfected between patients using Environmental Protection Agency (EPA)- registered disinfectants that are compatible with the mattress cover materials to prevent tears, cracks and holes in the cover. Finally, the CDC recommend laundering mattress covers that are made of fabric and all pillow covers.

The Centers for Disease Control and Prevention (CDC), in its most recent guideline for disinfection and sterilization in healthcare facilities, considers many areas of the patient room to be "non-critical" and does not make specific recommendations for cleaning standards for these areas [5]. According to this guideline, bedrails are non-critical surfaces. The mattress and bed deck are not specifically adressed in the new guidelines. Several studies have shown that the entire hospital room, and especially the hospital bed, commonly remains contaminated even after terminal cleaning, the cleaning that occurs after the patient is discharged [6-9]. Recent studies have shown that, if the previous occupant had infections with methicillin-resistant Staphylococcus aureus (MRSA), vancomycin-resistant Enterococcus (VRE), or Clostridium difficile, there is a significantly increased risk of the subsequent patient contracting diseases caused by these organisms [10-12].

Several studies have documented the hospital mattress as a vector for HAIs. In England, two different research teams have isolated Pseudomonas aeruginosa inside mattresses during outbreaks of $P$. aeruginosa at their facilities [13,14]. Another English hospital cultured MRSA from foam mattresses during an outbreak of MRSA [15]. In the United States, Canada, and England, antibioticresistant strains of Acinetobacter have been isolated from mattresses during outbreaks of Acinetobacter in burn units [16-18]. One incubator mattress was implicated in an outbreak of neonatal gastroenteritis with Samonellawien [19]. There is published evidence that demonstrates enhanced cleaning of the hospital room may help decrease the transmission of infections from the environment [20-23].

In the hospital environment, other than the operating room, the guiding principle for cleaning has been to decrease contamination without any attempt to achieve sterilization. Three authors have proposed levels of bacterial contamination that might be an acceptable standard for assessing terminal cleaning of hospital rooms [24-26]. Unfortunately, there is no evidence that these levels of contamination are low enough to help prevent HAIs.

In order to provide the cleanest possible environment for patients, many hospitals have enhanced cleaning efforts in rooms. Curtains are no longer simply cleaned when they are visually soiled; they are replaced after each patient use because research has shown how contaminated curtains can become. Some hospitals are testing the use of ultraviolet lights and hydrogen peroxide as means to more effectively kill bacteria and decrease hospital-acquired infections. However, one area that has not received enough attention is the hospital bed. Of all of the areas in the hospital room, the hospital bed is the object with which patients have the most contact.

Determining the level of bacterial contamination in hospital rooms is critical to developing housekeeping methods to decrease HAIs. The Centers for Medicare and Medicaid Services have recently mandated that hospitals enact an infection prevention and control program that includes "appropriate monitoring of housekeeping...to ensure that the hospital maintains a sanitary environment." [27]

In 2011, Trinity Guardion (Batesville, IN) developed a launderable cover for hospital beds. This cover is engineered to protect the mattress and the bed deck from contamination, and it allows hospitals to launder the cover between patients. There are no published studies evaluating the performance of these covers in the clinical environment.

The current research focuses on the potential ability of these new launderable covers to reduce bacterial contamination of hospital beds. Prior research on bacterial contamination in hospitals has used a number of methods for enumerating bacteria on surfaces. A commonly reported method is to utilize moistened cotton-tip or rayon-tipped swabs $[7,12,28,29]$. In recent years several authors have used contact plates, Replicate Organism Detection and Counting (RODAC ${ }^{\mathrm{m}}$ ) and contact slides $\left(D^{2}\right.$ IPLIDE $\left.^{\mathrm{Tm}}\right)$, to detect and enumerate bacteria on environmental surfaces $[8,30]$. Other authors have described using gauze to rub the surface [18].

In the food industry, it is common to use Petrifilm ${ }^{\mathrm{mm}}$ plates $\left(3 \mathrm{M}^{\mathrm{sm}}\right.$, St. Paul, MN, USA) to enumerate bacterial counts in food processing plants. These plates are easy to use and do not require the use of a microbiological laboratory. One researcher used the Petrifilm ${ }^{\mathrm{Tm}}$ Staph Express Plates to detect methicillin-resistant Staphylococcus aureus (MRSA) on egg-crate mattresses [31].

The current research had three goals. The first goal was to evaluate how well terminal cleaning eliminates bacteria from hospital beds (mattresses and bed deck). The second goal was to compare bacterial contamination of beds after terminal cleaning to the contamination on a laundered cover. The third goal was to compare contamination on beds protected by a sheet to those covered with a launderable cover and a sheet.

\section{Materials and methods Petrifilm ${ }^{\mathrm{TM}}$}

Several styles of Petrifilm ${ }^{\text {Tw }}$ plates are available to identify bacterial contamination on surfaces. Petrifilm ${ }^{\mathrm{Ts}}$ Aerobic Count Plates $\left(\right.$ Petrifilm $^{\mathrm{\tau}}{ }^{\mathrm{M}}$ ) consist of standard bacterial nutrients in a cold-water soluble gel. The gel is manufactured 
and applied as a thin coating onto a sheet of clear flexible plastic material measuring $75 \mathrm{~mm}$ by $95 \mathrm{~mm}$. The plates are dehydrated and packaged 50-plates-per-pack. Plates must be hydrated with buffered peptone water broth prior to use. Red colonies on the gel identify bacterial growth. Hydrated plates were stored in clean plastic bags at $4{ }^{\circ} \mathrm{C}$ for up to two weeks prior to use. Each hydrated plate was applied to the surface being sampled for 10 seconds. Sampling was standardized so that samples were all taken from the center of the top of the mattress and bed deck.

\section{Hospital mattress}

All beds used in the study were Hill-Rom VersaCare ${ }^{\circledR}$ beds. The beds' mattresses each had an air mattress core and a cover made of non-permeable stamped layers of polyurethane coated nylon. All beds were located on a bariatric surgery unit of a community hospital.

\section{Launderable mattress cover}

The cover is made of a fluid-impermeable, breathable polyurethane fabric with knitted polyester backing. It is manufactured using welded seams (Trinity Guardion, Batesville, IN, USA) (Figure 1). Pockets on each end encapsulate the mattress and the cover fits snugly around the bed deck to keep fluids from being trapped between the bed deck and the mattress. The cover does not interfere with the operation of the bed and can be laundered in hot or cold water. Chlorine use does not damage the cover. During the study, each cover was laundered between uses in a commercial laundry using multiple cycles with detergent, chlorine bleach, and multiple hot water rinses. Covers were then dried at over $200^{\circ}$ Fahrenheit $\left(93^{\circ}\right.$ Celcius) for 30 minutes.

\section{Bed deck}

The bed deck is the metal frame upon which the hospital mattress rests.

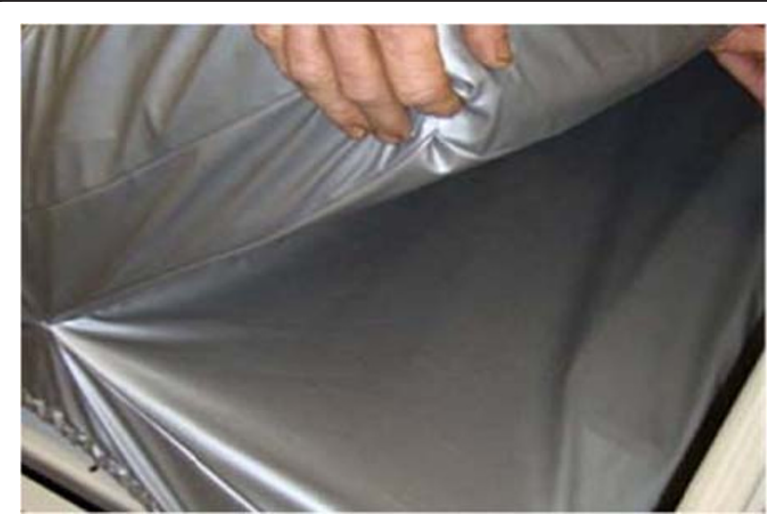

Figure 1 Launderable cover by Trinity Guardion showing how the cover protects both the mattress and bed deck.

\section{Randomization}

Beds were randomized to receive or not receive a launderable mattress and bed deck cover (launderable cover). Randomization was performed using a chart that assigned beds based on the time the page for terminal room clean request was received. Upon receiving a page that the room was ready to be cleaned, nursing staff determined if the bed would receive a launderable cover or not. Environmental services personnel cleaned the rooms, and were aware of the ongoing study of cleanliness of the mattresses.

\section{Cleaning of the standard mattress and bed deck}

All beds were cleaned using EnverrosSanimaster 4 (Ecolab Inc., St. Paul, MN) diluted 1:128. The disinfectant was prepared using an automated mixing system, and clean rags were used once and never returned to the cleaning solution. Beds were not cleaned using detergent prior to disinfection and were not rinsed after disinfection.

\section{Sampling procedure}

After rooms were terminally cleaned, the mattress surface and the bed deck of all beds were sampled. If the bed received a cover, the cover was sampled after being applied to the bed. All mattresses, with or without a launderable cover, were covered with clean sheets. When the patient was discharged, the bed linen was removed and the mattress surface and bed deck of all beds were sampled prior to terminal cleaning. If the mattress had received a launderable cover, that cover was sampled and then removed. The underlying mattress surface was then sampled. Environmental services then cleaned the bed, and the mattress surface and bed deck were again sampled. If the patient was discharged in less than 24 hours, the bed was removed from the study.

\section{Laboratory procedure}

Petrifilm ${ }^{\mathrm{TM}}$ plates were incubated for 24 hours at $37{ }^{\circ} \mathrm{C}$ in 5-7 \% CO2. After incubation, plate counts were performed visually. A red colony within the hydrated area was counted as one colony-forming unit (CFU). All counts were per $30 \mathrm{~cm}^{2}$. Counts of greater than $300 \mathrm{CFU}$ per $30 \mathrm{~cm}^{2}$ were recorded as "too-numerous-to-count" (TNTC). After performing the count, the Petrifilm ${ }^{\mathrm{TM}}$ plate was blotted onto $5 \%$ sheep blood agar medium (BA). Growth was examined after BA was incubated overnight at $37{ }^{\circ} \mathrm{C}$ in $5-7 \% \mathrm{CO} 2$. Bacteria were identified using standard laboratory methods.

\section{Statistics}

All calculations were performed using $\mathrm{IBM}^{\mathrm{sm}} \mathrm{SPSS}^{\mathrm{sm}}$ for Macintosh, version 19 (International Business Machines Corporation, Armonk, NY, USA). Growth was quantified using descriptive statistics. The t-test compared the means. 
Table 1 Launderable Cover provides a cleaner surface and prevents mattress contamination better than terminal cleaning with quaternary ammonia compound

\begin{tabular}{llll}
\hline & $\begin{array}{l}\text { Before Patient Use } \\
\left(\mathbf{C F U} / \mathbf{3 0} \mathbf{~ c m}^{\mathbf{2}}\right)\end{array}$ & $\begin{array}{l}\text { After Discharge } \\
\left(\mathbf{C F U} / \mathbf{3 0} \mathbf{~ c m}^{\mathbf{2}}\right)\end{array}$ & $\begin{array}{l}\text { After terminal cleaning } \\
\left(\mathbf{C F U} / \mathbf{3 0} \mathbf{~ c m}^{\mathbf{2}}\right)\end{array}$ \\
\hline Mattress Surface when NO Cover was used $(\mathrm{n}=38)$ & $7.7 \pm 14.5$ median $=3$ & $79.1 \pm 113.4$ median $=25$ & $12.8 \pm 48.2$ median $=3$ \\
Surface of Launderable Mattress Cover $(\mathrm{n}=28)$ & $1.1 \pm 1.2$ median $=1$ & $108 \pm 126$ median=35 & $1.1 \pm 1.2^{*}$ median=1 \\
Mattress Surface when a Launderable cover was used $(\mathrm{n}=28)$ & $2.5 \pm 2.7$ median $=2$ & $3.0 \pm 5.9$ median=1 & $3.7 \pm 8.0$ median $=1$ \\
\hline
\end{tabular}

1. Before patient use all beds were terminally cleaned using quaternary ammonia compound. Launderable covers were laundered prior sampling. All beds were covered with clean sheets prior to patient use.

2. After discharge, but prior to terminal cleaning.

${ }^{*}$ After laundering.

\section{Results}

Sixty-six beds were entered into the study: 38 that did not receive a launderable cover and 28 that did receive a launderable cover. All beds had been terminally cleaned using quaternary ammonia compound prior to being placed in the study, and after use, each bed was again cleaned using quaternary ammonia compound. The average length of stay was similar for both groups ( 89 hours for beds without a cover and 77 hours for those with a cover; $\mathrm{p}=0.530$ ).

The launderable cover was significantly cleaner prior to patient use than were the mattresses, which had been terminally cleaned $(\mathrm{p}=0.0189)$ (Table 1$)$. The mean colony count, prior to patient use, on the 38 mattresses that did not receive a launderable cover was $7.7 \mathrm{CFU} / 30 \mathrm{~cm}^{2}$ (median $3 \mathrm{CFU} / 30 \mathrm{~cm}^{2}$; SD 14.5). The mean colony count, prior to patient use, on the launderable cover was 1.1 CFU/ $30 \mathrm{~cm}^{2}$ (median $1 \mathrm{CFU} / 30 \mathrm{~cm}^{2}$; SD 1.2).

After the patient was discharged, surfaces were again cultured. The mattresses that did not utilize a launderable cover had significant increases in their bacterial counts (7.7 CFU/30 $\mathrm{cm}^{2}$ (median $3 \mathrm{CFU} / 30 \mathrm{~cm}^{2}$; SD 14.5) on admission vs. $79.1 \mathrm{CFU} / 30 \mathrm{~cm}^{2}$ (median $25 \mathrm{CFU} / 30 \mathrm{~cm}^{2}$; SD 113.4) at discharge; $p=0.001$ ). When the launderable cover was utilized, there was no significant change in bacterial counts on the surface of the mattress (2.5 CFU/ $30 \mathrm{~cm}^{2}$ (median $2 \mathrm{CFU} / 30 \mathrm{~cm} 2$; SD 2.7) on admission vs. $3.0 \mathrm{CFU} / 30 \mathrm{~cm}^{2}$ (median $1 \mathrm{CFU} / 30 \mathrm{~cm} 2$; SD 5.9) at discharge; $\mathrm{p}=0.703$ ).

Final testing was performed after the beds were terminally cleaned prior to the next patient. After this terminal cleaning, the mattress surface contamination was decreased from $79.1 \mathrm{CFU} / 30 \mathrm{~cm}^{2}$ (median $25 \mathrm{CFU} / 30 \mathrm{~cm}^{2}$; SD 113.4) to 12.8 (median $3 \mathrm{CFU} / 30 \mathrm{~cm}^{2}$; SD 48.2 ) in beds that did not use a cover, which is only an $84 \%$ reduction (less than $\log 2$ reduction).

\section{Contamination of the bed deck}

The bed decks of all beds prior to patient use were more contaminated than the mattress surfaces. The mean colony count, prior to patient use, on the 38 bed decks of beds that did not receive a launderable cover was $33.0 \mathrm{CFU} / 30 \mathrm{~cm}^{2}$ (median $4 \mathrm{CFU} / 30 \mathrm{~cm}^{2}$; SD 100.8). The mean colony count, prior to patient use, on bed decks that received a launderable cover was $28.2 \mathrm{CFU} / 30 \mathrm{~cm}^{2}$ (median $2 \mathrm{CFU} /$ $30 \mathrm{~cm}^{2}$; SD 78.2) (Table 2).

After the patient was discharged, the bed deck was again tested. The bed deck that did not utilize a launderable cover had significantly more bacteria than did the bed decks that had utilized a cover $\left(10.3 \mathrm{CFU} / 30 \mathrm{~cm}^{2}\right.$ (median $1.5 \mathrm{CFU} /$ $30 \mathrm{~cm}^{2}$; SD 25.9) vs. $1.9 \mathrm{CFU} / 30 \mathrm{~cm}^{2}$ (median $1 \mathrm{CFU} /$ $30 \mathrm{~cm}^{2}$; SD 3.6); $\mathrm{p}=0.011$ ).

Final testing was performed on the bed deck after the beds were terminally cleaned. After this terminal cleaning, the bed deck was more contaminated than before terminal cleaning (Table 2) $(\mathrm{p}=0.031)$. The mean colony count, after discharge, on the 66 bed decks was $6.7 \mathrm{CFU} / 30 \mathrm{~cm}^{2}$ (median $1 \mathrm{CFU} / 30 \mathrm{~cm}^{2}$; SD 20.2). The mean colony count, after terminal cleaning, on the 66 bed decks increased to $30.9 \mathrm{CFU} / 30 \mathrm{~cm}^{2}$ (median $2 \mathrm{CFU} / 30 \mathrm{~cm}^{2}$; SD 86.1). Most commonly the bacteria had been present on both the bed deck and mattress after discharge, but the counts were significantly higher after terminal cleaning. There was one bed where $P$. aeruginosa was present on the mattess after discharge but not on the bed deck. After terminal cleaning, the $P$. aeruginosa was present on both the mattress and the bed deck.

Table 2 Launderable cover protects the bed deck from bacterial contamination during patient use

\begin{tabular}{|c|c|c|c|}
\hline & $\begin{array}{l}\text { Before Patient Use } \\
\left.\text { (CFU/30 } \mathrm{cm}^{2}\right)\end{array}$ & $\begin{array}{l}\text { After Discharge } \\
\left(\text { CFU/30 cm }{ }^{2}\right)\end{array}$ & $\begin{array}{l}\text { After terminal cleaning } \\
\left(\mathrm{CFU} / 30 \mathrm{~cm}^{2}\right)\end{array}$ \\
\hline Bed Deck when NO cover utilized $(n=38)$ & $33.0 \pm 100.8$ median $=4$ & $10.3 \pm 25.9$ median $=1.5$ & $43.5 \pm 101.6$ median $=2$ \\
\hline Bed Deck when Launderable Mattress Cover utilized $(n=28)$ & $28.2 \pm 78.2$ median $=2$ & $1.9 \pm 3.6$ median $=1$ & $13.75 \pm 56.4$ median $=1$ \\
\hline All Bed Decks $(n=66)$ & $31.2 \pm 91.2$ median $=3$ & $6.7 \pm 20.2$ median $=1$ & $30.9 \pm 86.1$ median $=2$ \\
\hline
\end{tabular}

1. Before patient use all beds were terminally cleaned using quaternary ammonia compound.

2. After discharge, but prior to terminal cleaning. 


\section{Controls}

The mean bacterial count for control plates $(n=62)$ was $0.05 \mathrm{CFU} / \mathrm{cm}^{2}$ (with only 3 plates having any growth).

\section{Bacteria identified}

There were 6 samples taken for all beds in the study (one for the mattress surface and one for the bed deck at each of the three time points: pre-admission, dirty after discharge, and after terminal cleaning). An additional two samples were taken when a cover was utitilzed (one sample of the cover before use and one of the dirty cover after discharge). This gave a total of 452 samples. Many samples had multiple bacteria. The bacteria identified included coagulasenegative Staphylococcus, Bacillus species, Micrococcus species, Pseudomonas fluorescens, Pseudomonas aeruginosa, Corynebacterium species, mold, Streptococcusviridans, Rhizobium radiobacter, Paracoccusyeei and Acinetobacter baumannii (Table 3).

\section{Discussion}

It is clear from the current research that hospital mattresses become significantly contaminated during use, even though they are covered with bed linens. These mattresses remain contaminated with bacteria, even after terminal cleaning with quaternary ammonia compound. The use of a launderable mattress cover helps prevent contamination of the hospital mattress and provides a less contaminated environment for patients.

Bacterial contamination in the hospital environment is a risk factor for HAIs [32]. Several authors have demonstrated that current cleaning protocols do not adequately decontaminate hospital rooms $[6,8,33]$. Hospital mattresses are often the most contaminated areas of hospital rooms

Table 3 Bacteria isolated from mattress, bed deck, and launderable cover

\begin{tabular}{llc}
\hline Bacteria & $\begin{array}{l}\text { Number of } \\
\text { cultures with } \\
\text { bacteria }\end{array}$ & $\begin{array}{l}\text { Percent of } \\
\text { total number } \\
\text { of cultures }\end{array}$ \\
\hline Coagulase-negative Staphylococcus & 281 & $62.2 \%$ \\
Bacillus species & 93 & $20.6 \%$ \\
Micrococcus species & 83 & $18.4 \%$ \\
Corynebacterium & 13 & $2.9 \%$ \\
Pseudomonas flourescens & 9 & $2.0 \%$ \\
Mold & 9 & $2.0 \%$ \\
Streptococcus viridians & 6 & $1.3 \%$ \\
Pseudomonas aeruginosa & 5 & $1.1 \%$ \\
Pseudomonas pseudoalcaligenes & 1 & $0.2 \%$ \\
Acinetobacter baumannii & 1 & $0.2 \%$ \\
Paracoccusyeei & 1 & $0.2 \%$ \\
Rhizobium radiobacter & 1 & $0.2 \%$ \\
\hline
\end{tabular}

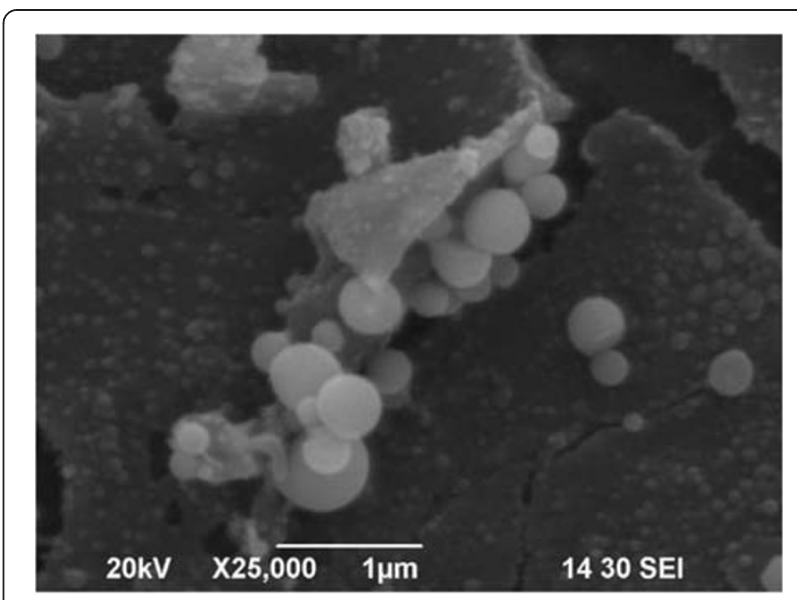

Figure 2 Scanning electron microscope picture of a polyurethane mattress surface showing cracking and bacterial contamination.

[9,30]. Evaluating the hospital environment for contamination can be done by several published methods including bacterial sampling (using swabs, gauze, Dipslide, and RODAC) and measurement for organic matter (using adenosine triphosphate [ATP]) [7,8,12,18,26,28-30]. The current research utilized Petrifilm ${ }^{\text {тм }}$ plates developed by $3 \mathrm{M}$ Corporation for use in the food industry. Petrifilm ${ }^{\mathrm{TM}}$ plates do not require technical expertise to use or interpret. One other research team has used a different Petrifilm ${ }^{\text {тм }}$ product, Staph Express Plates, to identify the presence of MRSA on egg-crate mattresses [31].

In the current study, terminal cleaning failed to eliminate bacteria from the surface of the mattress. Because of this contamination, mattresses that are damaged could allow for bacteria to contaminate the foam interior of the mattress, and this contamination has been linked to HAIs [1319]. A scanning electron microscope picture of one of the mattresses utilized in the study shows the mattress cover to be both cracked and contaminated with bacteria (Figure 2). The research also demonstrated that the bed deck is more contaminated after terminal cleaning (Table 2). This may be a result of cross-contamination from the mattress surface.

A recent Field Safety Notice from Hill-Rom noted that beds "must be kept clean at all times in order to avoid a risk of infection. When cleaning, always check the cover for cuts, tears, cracks, pin holes or snags. Never use a mattress with a damaged cover-replace it before the inner core of the mattress becomes contaminated. If the internal foam of the mattress is soiled, you are advised to replace it as well." [34]

The cleaner used in the current study was a quaternary ammonium compound (Quat), which is the most commonly used disinfectant in the United States [35]. The Environmental Protection Agency (EPA) has approved Quats for use on hard non-porous surfaces. The mattress 
surfaces are soft surfaces. The Quats have "a tendency to become attracted to and absorbed into fabrics." [36] Quats are cationic (positively charged) and fabric is anionic (negatively charged), which can cause the chemicals to bind to the fabric and damage it.

In order to be classified as a disinfectant by the EPA, a product must "destroy or irreversibly inactivate infectious fungi and bacteria." [37] In order to claim efficacy, the EPA requires that disinfectants kill at least 59 of 60 (98\%) samples placed on hard surfaces, and it must destroy more than $10^{6}$ organisms on each plate, after a 10 minute dwell time $[38,39]$. The EPA does not certify these chemicals for use on soft or porous surfaces, the type of surface generally found on hospital beds and furniture. In the current study, the disinfectant only decreased bacterial counts on the mattress surface by $84 \%$, and only $16 \%$ of samples had no growth. This is concerning because, according to published reports, as few as 10 organisms can produce an infection, and bacteria can survive for months on dry surfaces [40-44].

The launderable mattress cover tested in the current study can be cleaned using heat and chlorine without damaging the cover. The manufacturer states that the cover could, if needed, be sterilized. The launderable covers were much cleaner than the surface of the terminally cleaned mattress. The cover also prevented the permanent mattress surface from contamination during use, which could have prevent transmission of bacteria to the next patient. Several studies have demonstrated the significantly increased risk of the subsequent patient contracting diseases when the previous patient had an infection with MRSA, VRE, or C. difficile [10-12].

The present research had limitations: (a) Only a small area of each mattress, bed deck or launderable cover was sampled. (b) The environmental services staff was aware of the purpose of the study, and they may have performed more effective cleaning during the study.

Most mattresses that have undergone terminal cleaning are still contaminated with bacteria. The newlydeveloped launderable cover provides a less contaminated surface and protects the mattress from contamination by the patient.

\section{Competing interest}

Funding for the research was received by Xavier University from a private foundation on which an investor in Trinity Guardion, maker of a launderable mattress cover, serves.

\section{Authors' contributions}

EAH participated in the planning of the research, management of the project, data analysis, and manuscript preparation. SDA participated in the planning of the research, directed the laboratory analysis of microbiological growth, and participated in manuscript preparation. LDG participated in planning the research and manuscript preparation. CK participated in the planning of the research, performed the laboratory analysis, and participated in the manuscript preparation. All authors read and approved the final manuscript.

\section{Author details}

'Department of Health Services Administration, Xavier University, 3800 Victory Parkway, ML 5141, Cincinnati, OH 45207-7331, USA. ²Department of Pathology and Laboratory Medicine, Indiana University School of Medicine, IU Health Pathology Laboratory, 350 W. 11th Street, Indianapolis, IN 46202, USA. ${ }^{3}$ TriHealth Clinical Microbiology Laboratory, 619 Oak Street, Cincinnati, OH 45206, USA. ${ }^{4}$ IU Health Pathology Laboratory, 350 W. 11th Street, Indianapolis, IN 46202, USA.

Received: 22 May 2012 Accepted: 26 July 2012

Published: 26 July 2012

\section{References}

1. Stone PW, Larson E, Kawar LN: A systematic audit of economic evidence linking nosocomial infections and infection control interventions: 19902000. Am J Infect Control 2002, 30(3):145-52.

2. Scott RD: The direct medical costs of healthcare-associated infections in U.S. hospitals and the benefits of prevention.: ; 2009. http://www.cdc.gov/HAl/ burden.html. Accessed 05/11, 2012.

3. Klevens RM, Edwards JR, Richards CL, Horan TC, Gaynes RP, Pollock DA, Cardo DM: Estimating Health Care-Associated Infections and Deaths in U. S. Hospitals, 2002. Public Health Rep 2007, 122:160-6.

4. Sehulster L, Chinn RYW: Guidelines for environmental infection control in health-care facilities: Recommendations of CDC and the healthcare infection control practices advisory committee(HICPAC). Morb Mortal Weekly Rep. 2003, 52(RR 10):1-44.

5. Rutala WA, Weber M: Guideline for disinfection and sterilization in healthcare facilities.: ; 2008. http://www.cdc.gov/hicpac/Disinfection_Sterilization/ 20_00reference.html. Accessed 12/2009, 2009.

6. Blythe D, Keenlyside D, Dawson SJ, Galloway A: Environmental contamination due to methicillin-resistant Staphylococcus aureus (MRSA). J Hosp Infect 1998, 38(1):67-9.

7. Denton M, Wilcox MH, Parnell P, Green D, Keer V, Hawkey PM, Evans I, et al: Role of environmental cleaning in controlling an outbreak of Acinetobacter baumannii on a neurosurgical intensive care unit. J Hosp Infect 2004, 56(2):106-10.

8. Andrade D, Angerami ELS, Padovani CR: A bacteriological study of hospital beds before and after disinfection with phenolic disinfectant. Rev Panam Salud Publica 2000, 7:179-84.

9. French GL, Otter JA, Shannon KP, Adams NMT, Watling D, Parks MJ: Tackling contamination of the hospital environment by methicillinresistant Staphylococcus aureus (MRSA): a comparison between conventional terminal cleaning and hydrogen peroxide vapour decontamination. J Hosp Infect 2004, 57(1):31-7.

10. Datta R, Platt R, Yokoe DS, Huang SS: Environmental Cleaning Intervention and Risk of Acquiring Multidrug-Resistant Organisms From Prior Room Occupants. Arch Intern Med 2011, 171(6):491.

11. Huang SS, Datta R, Platt R: Risk of acquiring antibiotic-resistant bacteria from prior room occupants. Arch Intern Med 2006, 166(18):1945-51.

12. Drees M, Snydman DR, Schmid CH, Barefoot L, Hansjosten K, Vue PM, Cronin $M$, et al: Prior environmental contamination increases the risk of acquisition of vancomycin-resistant enterococci. Clin Infect Dis 2008, 46(5):678.

13. Robertson MH, Hoy G, Peterkin IM: Anti-static mattress as reservoir of Pseudomonasinfection. Br Med J 1980, 280:831-2.

14. Fujita K, Lilly HA, Kidson A, Ayliffe GA: Gentamicin-resistant Pseudomonas aeruginosa infection from mattresses in a burns unit. Br Med J (Clin Res Ed) 1981, 283(6285):219.

15. Ndawula EM, Brown L: Mattresses as reservoirs of epidemic methicillinresistant Staphylococcus aureus. Lancet 1991, 337(8739):488.

16. Sherertz RJ, Sullivan ML: An outbreak of infections with Acinetobacter calcoaceticus in burn patients: contamination of patients' mattresses. $J$ Infect Dis 1985, 151(2):252-8.

17. Loomes S: The Journal of Infection Control Nursing. Is it safe to lie down in hospital? Nurs Times 1988, 84(49):63-5.

18. Simor AE, Lee M, Vearncombe M, Jones-Paul L, Barry C, Gomez M, Fish JS, et al: An outbreak due to multiresistant Acinetobacter baumannii in a burn unit: risk factors for acquisition and management. Infect Control Hosp Epidemiol 2002, 23(5):261-7.

19. Hammami A, Arlet G, Ben Redjeb S, Grimont F, Ben Hassen A, Rekik A, Philippon A: Nosocomial outbreak of acute gastroenteritis in a neonatal intensive care unit in tunisia caused by multiply drug resistant 
Salmonella wien producing SHV-2 beta-lactamase. Eur J Clin Microbiol Infect Dis 1991, 10(8):641-6.

20. Martinez JA, Ruthazer R, Hansjosten K, Barefoot L, Snydman DR: Role of environmental contamination as a risk factor for acquisition of vancomycin-resistant enterococci in patients treated in a medical intensive care unit. Arch Intern Med 2003, 163(16):1905-12.

21. Noone P, Griffiths RJ: The effect on sepsis rates of closing and cleaning hospital wards. J Clin Pathol 1971, 24(8):721.

22. Dancer SJ, White LF, Lamb J, Girvan EK, Robertson C: Measuring the effect of enhanced cleaning in a UK hospital: a prospective cross-over study. BMC Med 2009, 7:28,

23. Carling PC, Parry MM, Rupp ME, Po JL, Dick B, Von Beheren S: Improving cleaning of the environment surrounding patients in 36 acute care hospitals. Infect Control Hosp Epidemiol 2008, 29(11):1035-41.

24. Dancer SJ: How do we assess hospital cleaning? A proposal for microbiological standards for surface hygiene in hospitals. $J$ Hosp Infect 2004, 56(1):10-5.

25. Eriksson B, Hoborn J, Nystrom B, Barrie D, Hoffman PN: The contact plate technique is inappropriate for bioburden determination on textiles. Authors' reply. J Hosp Infect 1995, 30(1):73-5.

26. Lewis T, Griffith C, Gallo M, Weinbren M: A modified ATP benchmark for evaluating the cleaning of some hospital environmental surfaces. $\int$ Hosp Infect 2008, 69(2):156-63.

27. Centers for Medicare and Medicaid Services: State operations manual: Appendix A-survey protocol, regulations and interpretive guidelines for hospitals. http://www.cms.gov/manuals/downloads/som107ap_a_hospitals. pdf. Accessed 07/14, 2011.

28. Byers KE, Durbin LJ, Simonton BM, Anglim AM, Adal KA, Farr BM: Disinfection of hospital rooms contaminated with vancomycin-resistant Enterococcus faecium. Infect Control Hosp Epidemiol 1998, 19(4):261-4.

29. Landers TF, Hoet A, Wittum TE: Swab Type, Moistening, and

Preenrichment for Staphylococcus aureus on Environmental Surfaces. $J$ Clin Microbiol 2010, 48(6):2235.

30. Dancer SJ, Coyne M, Speekenbrink A, Samavedam S, Kennedy J, Wallace PGM: MRSA acquisition in an intensive care unit. Am J Infect Control 2006, 34(1):10-7.

31. Ferreira AM, Andrade D, Almeida MTG, Cunha KC, Rigotti MA: Egg crater mattresses: a deposit of methicillin-resistant staphylococcus aureus? Revista da Escola de Enfermagem da USP. 2011, 45(1):161-6.

32. Carling PC, Bartley JM: Evaluating hygienic cleaning in health care settings: What you do not know can harm your patients. Am J Infect Control 2010, 38(5):S41-50.

33. Hardy KJ, Oppenheim BA, Gossain S, Gao F, Hawkey PM: A study of the relationship between environmental contamination with methicillinresistant Staphylococcus aureus (MRSA) and patients' acquisition of MRSA. Infect Control Hosp Epidemiol 2006, 27(2):127-32.

34. Anonymous. Hill-Rom Urgent Field Safety Notice Hill-Rom ${ }^{\circledR}$ NP150 Viscoelastic Mattress. 2011

35. Sattar SA: Promises and pitfalls of recent advances in chemical means of preventing the spread of nosocomial infections by environmental surfaces. Am J Infect Control 2010, 38(5):S34-40.

36. Ecolab. Quat absorption onto textiles. http://www.ndhealth.gov/disease/hai/ Docs/QuatAbsorptionEcoLab.pdf. Accessed 05/09, 2012

37. http://www.epa.gov/oppad001/ad_info.htm. Accessed 04/29, 2012

38. Anonymous. Disinfectants for use on hard surfaces: DIS/TSS-1 jan 22, 1982 efficacy data requirements, 05/09/2012. http:/www.epa.gov/oppad001/ dis_tss_docs/dis-01.htm. Accessed 05/16, 2012

39. Anonymous. Standard operating procedure for AOAC use dilution method for testing disinfectants, 02/14/2010. http:/www.epa.gov/opp00001/methods/ atmpmethods/MB-05-08.pdf. Accessed 05/16, 2012.

40. Kramer A, Schwebke I, Kampf G: How long do nosocomial pathogens persist on inanimate surfaces? A systematic review. BMC Infect Dis 2006, 6:130.

41. Elek SD: Experimental staphylococcal infections in the skin of man. Ann $N$ Y Acad Sci 1956, 65(3):85-90.

42. Marples RR: Local infections experimental aspects. J Soc Cosmet Chem. 1976, 27:449-57.

43. Marples RR, Kligman AM: Bacterial infection of superficial wounds: a human model for Staphylococcus Aureus. In Epidermal Wound Healing. Edited by Maibach HI, Rovee DT. Chicago: Year Book Medical Publishers, Inc:i 1972:241-54.
44. Singh G, Marples RR, Kligman AM: Experimental Staphylococcus aureus infections in humans. J Invest Dermatol 1971, 57(3):149-62.

doi:2047-2994-1-27

Cite this article as: Hooker et al:: A randomized trial to evaluate a launderable bed protection system for hospital beds. Antimicrobial Resistance and Infection Control 2012 :

\section{Submit your next manuscript to BioMed Central and take full advantage of:}

- Convenient online submission

- Thorough peer review

- No space constraints or color figure charges

- Immediate publication on acceptance

- Inclusion in PubMed, CAS, Scopus and Google Scholar

- Research which is freely available for redistribution 